\title{
Stable isotope compositions of fluid inclusions in biogenic carbonates
}

\author{
C. LECUYER' ${ }^{1}$ and J. R. O'NEIL ${ }^{2}$ \\ 'Laboratoire de Géochimie Isotopique, Géosciences Rennes, UPR4661 CNRS, Campus de Beaulieu, \\ Université de Rennes I, 35042 Rennes, France \\ ${ }^{2}$ Stable Isotope Laboratory, Department of Geological Sciences, University of Michigan, \\ 1006 C. C. Little Building, Ann Arbor, MI 48109-1063, USA
}

(Received August 20, 1992; accepted in revised form July 8, 1993)

\begin{abstract}
Measurements have been made of hydrogen, carbon, and oxygen isotope compositions of inclusion waters and $\mathrm{CO}_{2}$ extracted from eleven species of modern marine and freshwater skeletal carbonates. The samples were collected in environments of highly contrasting temperatures and isotopic compositions of ambient waters. Inclusion waters were extracted in vacuum by thermal decrepitation of samples that were previously treated with $\mathrm{H}_{2} \mathrm{O}_{2}$ to remove organic matter. Water extractions were quantitative above $200^{\circ} \mathrm{C}$ for aragonite species and above $350-400^{\circ} \mathrm{C}$ for calcite species. Amounts of water liberated ranged from $0.6 \%$ to $2,2 \%$ and were generally very reproducible within a species but varied strongly from one species to another. Except for red algae and corals, the $\delta^{18} \mathrm{O}$ values of the shells are in accord with crystallization of carbonate at or near equilibrium with marine water of $\delta^{18} \mathrm{O}$ near $0 \%$. The inclusion waters, however, are not in oxygen isotope equilibrium with ambient water and have high $\delta^{18} \mathrm{O}$ values of +6 to $+18 \%$. These high ${ }^{18} \mathrm{O}$ values do not result from partial exchange between water and either the host carbonate or small amounts of $\mathrm{CO}_{2}$ released during decrepitation. $\delta \mathrm{D}$ values of inclusion waters range from -80 to $-10 \%$ and are sensitive to the presence of small amounts of organic matter. The data for each species define a distinct field in $\delta \mathrm{D}-\delta{ }^{18} \mathrm{O}$ space that is controlled by a vital fractionation effect. Stable isotope compositions of inclusion waters can be explained by metabolic reactions that incorporate relatively ${ }^{18} \mathrm{O}$-rich $\mathrm{O}_{2}$ that is dissolved in the water and used by the organism in respiration. Thus, inclusion waters in shells probably represent remnants of metabolic fluids produced by the mantle epithelium. The stable isotope compositions of such waters most likely result from varying metabolic rates that are specific to each species, as well as to formation temperature and the isotopic composition of ambient waters.

Inclusion fluids in biogenic carbonates constitute an isotopic reservoir that has heretofore been unrecognized. The $\delta^{18} \mathrm{O}$ and $\delta \mathrm{D}$ values of the inclusion watcrs are very different from those of meteoric, magmatic, and seawaters. Because these trapped fluids are released by the shells during heating, they could play a role in burial diagenesis. Burial of significant amounts of biogenic carbonates could liberate enough water to control diagenetic or metamorphic reactions in some cases. In the absence of other types of fluids, the participation of inclusion waters in such reactions should be easily recognized by their distinctive isotopic compositions.
\end{abstract}

\section{INTRODUCTION}

SKELETAL CARBONATES contain abundant water (up to $3 \%$ ) that is trapped mainly in minute inclusions and that is readily released during heating (GAFFEY, 1988). More is known about the stable isotope geochemistry of carbonates and waters than of any other substance and yet measurements of the stable isotope compositions of inclusion waters in biogenic carbonates have not previously been reported. The presence of fluid inclusions in shells has long been recognized by carbonate petrologists, but only since the publications of GAFFEY (1988) and GAFFEY et al. (1991) have the relatively large amounts of such fluids and their possible role in diagenetic reactions been appreciated. Chemical and stable isotope analyses of these fluids will clearly provide important information on the nature and origin of the inclusion fluids. The goal of the present research was to develop analytical methods to make reliable isotopic measurements and to obtain preliminary data that delineate general isotopic systematics among selected species of marine and freshwater organisms.

Inclusion fluids in skeletal carbonates can represent a significant isotopic reservoir that may become involved in burial diagenesis or metamorphic reactions with exotic rocks in contact with biogenic carbonates. The field of $\delta \mathrm{D}-\delta^{18} \mathrm{O}$ values for the inclusion waters is quite different from those of other well-known reservoirs like magmatic, metamorphic, and meteoric waters. This new isotopic reservoir should be taken into considcration when interpreting stable isotope variations of diagenetic carbonates in burial metamorphic settings.

One of the main objectives of this study is to ascertain the origin of the inclusion fluids using stable isotope measurements. Stable isotope fractionations accompanying certain low-temperature geological processes and many biological processes are, however, controlled by kinetic factors and bear no relation to corresponding equilibrium fractionations in the system. Several early studies (e.g., EPSTEIN et al., 1953; WEBER and RAUP, 1966) emphasized the fact that tests of certain organically precipitated carbonates, like corals, can be severely out of carbon and oxygen isotope equilibrium with ambient waters. Such isotopic fractionations are interpreted to be a consequence of a vital effect and are known only from empirical observations. Most marine invertebrates like molluscs incorporate ambient water into their systems, modify its chemistry through metabolic processes, and pro- 
TABLE 1. Nomenclature, mineralogy and location of the biogenic carbonates studied.

\begin{tabular}{|c|c|c|c|c|}
\hline Subkingdom & Super class or class & Genus & Mineralogy & Lecation \\
\hline \multirow[t]{2}{*}{ Mollusca } & Bivalvia & $\begin{array}{l}\text { Pododesmus macrochisma } \\
\text { Anadara notabilis } \\
\text { Arca zebra } \\
\text { Mytilus edulis } \\
\text { Merceneria merceneria } \\
\text { clam - unidentified }\end{array}$ & $\begin{array}{l}\text { calcite } \\
\text { aragonite } \\
\text { aragonite } \\
\text { aragonite }+ \text { calcite } \\
\text { aragonite } \\
\text { aragonite }\end{array}$ & $\begin{array}{l}\text { South Califomia } \\
\text { St. Moarten - Caribbean Sea } \\
\text { St. Maarten - Caribbean Sea } \\
\text { Maine - North Atlantic } \\
\text { Maine - North Atlantic } \\
\text { Lake Huron }\end{array}$ \\
\hline & Gastropoda & $\begin{array}{l}\text { Strombus gigas } \\
\text { Cittaritum pica } \\
\text { unidentified }\end{array}$ & $\begin{array}{l}\text { aragonite } \\
\text { aragonite } \\
\text { aragonite }\end{array}$ & $\begin{array}{l}\text { Florida } \\
\text { St. Maarten - Caribbean Sea } \\
\text { Lake Michigan }\end{array}$ \\
\hline Algae & Rhodophyceae & Red algae - unidentified & calcite & Florida \\
\hline Coelenterata & Anthozoa & Red coral - unidentified & aragonite & Florida \\
\hline
\end{tabular}

duce a fluid called the pallial fluid from which the carbonate shell is precipitated. For meaningful temperature information to be obtained from oxygen isotope analysis of carbonate shells, it must be assumed that the pallial fluids of the organisms are in isotopic equilibrium with the environmental fluids. But even brachiopod shells, often employed in studies of paleothermometry and related subjects because they are low$\mathrm{Mg}$ calcite, are commonly precipitated out of equilibrium with the ocean (CARPENTER, 1991). Thus, stable isotope characterization of the water trapped within skeletal carbonates will provide quantitative information on how the biological activity of different organisms can affect the isotopic composition of environmental fluids. The isotopic measurements will bear importantly on several aspects of biogenic carbonate formation including vital effects and the timing of carbonate precipitation.

\section{ANALYTICAL TECHNIQUES}

Eleven species of modern shells were collected from marine and freshwater environments in North and Central America. At the time of collection, the organisms were either living or recently dead so that the shells were in an excellent state of preservation. The locations sampled provide a great variability in the nature of the environmental waters. Taxonomy, mineralogy, and location are given in Table 1. Molluscs, algae, and coelenterata were selected from medium latitudes $\left(40^{\circ} \mathrm{N}\right)$ to tropical areas in marine waters. A few samples of bivalves and gastropods were taken from cold freshwaters of the Great Lakes.

\section{Skeletal Carbonates}

The samples were crushed with an agate mortar and pestle to millimeter-size pieces and treated with $30 \% \mathrm{H}_{2} \mathrm{O}_{2}$ for forty-eight h to remove organic compounds. Carbonate samples weighing between $10 \mu \mathrm{g}$ and $1 \mathrm{mg}$ were reacted at $72 \pm 2^{\circ} \mathrm{C}$ with three drops of anhydrous phosphoric acid for $8 \mathrm{~min}$ in a Finnigan-Mat Kiel extraction system coupled directly to the inlet system of a Finnigan-Mat 251 triple collector isotope ratio mass spectrometer. Isotopic analyses were corrected for acid fractionation and ${ }^{17} \mathrm{O}$ contribution and are reported in the per mil notation relative to PDB. The procedure has been calibrated with a best-fit regression line defined by accepted analyses of three NBS carbonate standards: NBS-18, NBS-19, and NBS-20. Measured precision is maintained at better than $0.1 \%$ for both carbon and oxygen isotope compositions (Table 2).

\section{Fluid Inclusions}

Thermal decrepitation was chosen as the method of extracting fluid inclusions for stable isotope analysis. The analytical procedure for their extraction and measurement is summarized in Fig. 1. Attempts to extract water by crushing were ineffective because of the minute size of fluid inclusions in most of the shells studied (GAFFEY, 1988). In the absence of contaminating substances like organic matter, thermal decrepitation should release water quantitatively from the carbonate inclusions without isotopic fractionation. After making multiple extractions for each species, it was concluded that extraction of water is quantitative above $200^{\circ} \mathrm{C}$ for aragonite and $350-400^{\circ} \mathrm{C}$ for calcite. No additional water was released on later heating of a test sample that had already been decrepitated.

After treatment with $\mathrm{H}_{2} \mathrm{O}_{2}$, samples weighing from 100 to $200 \mathrm{mg}$ were washed in distilled water, dried in air, and then degassed at

TABLE 2. $\delta^{18} \mathrm{O}$ and $\delta^{13} \mathrm{C}$ values of ten biogenic carbonates. Average values and $1 \sigma$ standard deviation for $\delta^{18} \mathrm{O}$ values of trapped waters are also given and used in Fig. 8.

\begin{tabular}{l|r|r|rr}
\hline Biogenic cartonate & $\begin{array}{r}\delta^{18} \mathrm{O} \text { shell } \\
\text { (PDB) }\end{array}$ & $\begin{array}{r}\delta^{13} \mathrm{C} \text { shell } \\
\text { (PDB) }\end{array}$ & $\begin{array}{r}\delta^{18} \mathrm{O}\left(\mathrm{H}_{2} \mathrm{O}\right) \\
(\mathrm{SMOW})\end{array}$ & $\begin{array}{r}\text { standard } \\
\text { deviation } \\
(1 \sigma)\end{array}$ \\
& & & & \\
\hline & & 0.71 & 11.4 & 2.01 \\
Pododesmus macrochisma & -0.29 & 1.86 & 16.9 & 1.02 \\
Anadara notabilis & -0.65 & 1.41 & 9.6 & 0.48 \\
Arca zebra & -0.54 & -0.29 & 15.0 & 1.16 \\
Strombus gigas & 0.25 & 2.36 & 13.4 & 0.95 \\
Cittarium pica & -0.46 & 0.22 & 7.1 & 0.84 \\
Merceneria merceneria & -1.38 & -6.65 & 6.3 & 0.28 \\
Freshwater clam & -6.46 & 0.13 & 10.2 & 1.10 \\
Freshwater gastropod & -5.13 & -1.04 & 16.7 & 0.76 \\
Coral & -2.52 & -4.23 & 12.0 & 0.32 \\
Red algae & -4.44 & & & \\
\hline
\end{tabular}




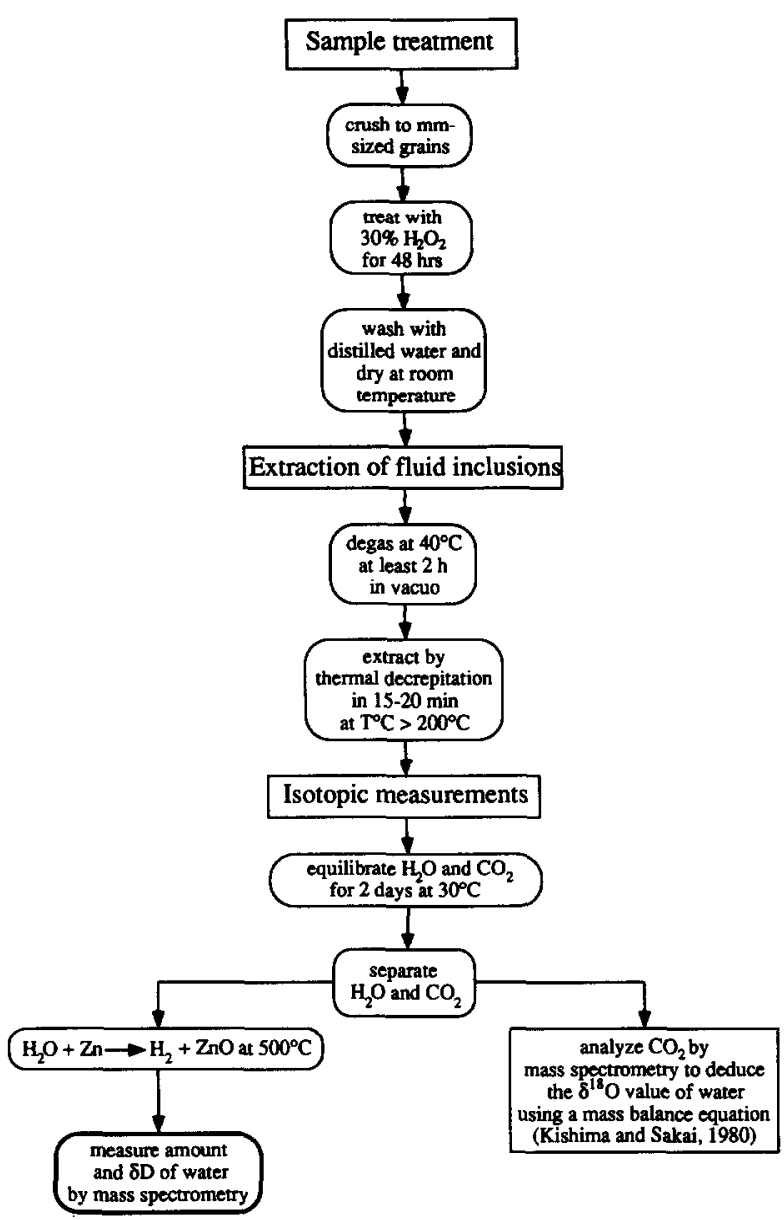

FIG. 1. Flow-chart summarizing the analytical procedure for the extraction and measurement of fluid inclusions in biogenic carbonates.

$40^{\circ} \mathrm{C}$ for a minimum of two hours under vacuum. The samples were then decrepitated and the condensible gases collected in a trap held at liquid nitrogen temperature. $\mathrm{CO}_{2}$ and $\mathrm{H}_{2} \mathrm{O}$ were then separated cryogenically and their volumes measured manometrically. Normally about $100-150 \mu$ moles of water were liberated during the decrepitations. This $\mathrm{H}_{2} \mathrm{O}$ was then transferred to a microequilibration vessel to which $30-40 \mu$ moles of tank $\mathrm{CO}_{2}$ were added. The $\mathrm{H}_{2} \mathrm{O}$ and tank $\mathrm{CO}_{2}$ of known amount and isotopic composition were then allowed to exchange oxygen isotopes at $30^{\circ} \mathrm{C}$ for two days. After this time equilibration was complete and the equilibrated samples of $\mathrm{H}_{2} \mathrm{O}$ and $\mathrm{CO}_{2}$ were separated cryogenically once again. The water was transferred to a tube containing zinc and reduced to hydrogen by heating the sealed tube for 20 minutes at $500^{\circ} \mathrm{C}$. This hydrogen was then expanded into a fixed volume on the inlet system of the mass spectrometer and a measurement was made of the intensity of the mass2 peak. These intensities have been carefully calibrated with hydrogen made from water of known and different amounts. Thus, the mass spectrometer is used to make accurate determinations of both the amount and $\mathrm{D}-\mathrm{H}$ ratio of water in the inclusions. The $\delta^{18} \mathrm{O}$ values of the water samples were calculated using the mass balance equation proposed by KISHIMA and SAK AI ( 1980) and the $\mathrm{CO}_{2}-\mathrm{H}_{2} \mathrm{O}$ fractionation factor at $30^{\circ} \mathrm{C}$ determined by O'NEIL and ADAMI (1969). The $\delta^{18} \mathrm{O}$ value of tank $\mathrm{CO}_{2}$ used for all equilibrations was $35.0 \%$ (SMOW), a value close to that expected for the $\mathrm{CO}_{2}$ after equilibration. Because the oxygen isotope ratio of the $\mathrm{CO}_{2}$ changes little during these equilibrations, the precision of the method is enhanced. Precisions routinely obtained in our laboratory are better than $0.2 \%$ for $\delta^{18} \mathrm{O}$ and $1 \%$ for $\delta \mathrm{D}$ for microliter quantities of water.

\section{STABLE ISOTOPE COMPOSITIONS}

\section{Skeletal Carbonates}

The $\delta^{13} \mathrm{C}$ and $\delta^{18} \mathrm{O}$ values of $\mathrm{CaCO}_{3}$ selected from the eleven shells are reported in Table 2. Despite the $\mathrm{H}_{2} \mathrm{O}_{2}$ treatment which removes almost all the organic carbon, $\delta^{13} \mathrm{C}$ values still record significant variations ranging from -4.2 to $+2.4 \%$ for marine species and -6.6 to $0.1 \%$ for freshwater species. The molluscs analyzed generally have $\delta^{18} \mathrm{O}$ values close to that expected for equilibrium precipitation from normal seawater. Despite colder water temperatures, the Merceneria merceneria specimen has a $\delta^{18} \mathrm{O}$ value of $-1.4 \%$, in keeping with the fact that seawater in the Maine area of the North Atlantic has a rather negative $\delta^{18} \mathrm{O}$ value of around $-2 \%$ because of freshwater inputs (EPSTEIN and MAYEDA, 1953; CRAIG and GORDON, 1965). Other species like algae and corals have low values down to $-4.4 \%$ and come from the tropical waters of the Florida Keys. It is well known that reef corals do not precipitate their skeletons in isotopic equilibrium with seawater (EPSTEIN et al., 1953; WEBER and WOODHEAD, 1970; SWART, 1983). WeIL et al. (1981) observed that corals precipitate $\mathrm{CaCO}_{3}$ that is $2.8-3.0 \%$ lighter than equilibrium aragonite and that the exact value of the offset from equilibrium is considered taxonomically specific. SWART (1983) proposed that such oxygen and carbon isotope disequilibrium fractionations result from changes in the relation between photosynthesis and respiration in different geographical locations. EPSTEIN et al. (1953), WEBER and WoOdHEAd (1970), Goreau (1977), and EREZ (1978) concluded that the isotopic compositions of coral skeletons reflect a vital effect that may be attributed to metabolic isotope fractionations. More recently, MCCONNAUGHEY (1989a,b) emphasized the existence of two patterns of isotopic disequilibria. The first one, a kinetic disequilibrium, occurs during $\mathrm{CO}_{2}$ hydration and hydroxylation and involves depletion of ${ }^{18} \mathrm{O}$ by as much as $4 \%$. The second one, metabolic effect, involves changes in $\delta^{13} \mathrm{C}$ values that are controlled by photosynthesis and respiration. The freshwater species clearly record isotopic compositions that are in agreement with isotopically light Lake Huron and Lake Michigan whose $\delta^{18} \mathrm{O}$ values vary seasonally from -8 to $-6 \%$ (D. L. Dettman and K. C. Lohmann, pers. commun.).

\section{Fluid Inclusions}

\section{Amount of water}

Reproducible amounts of water are obtained from repeated extractions at temperatures above $200^{\circ} \mathrm{C}$ for aragonite shell from the same species (e.g., Anadara notabilis, Arca zebra, and Strombus gigas; Table 3 ). Amounts of water vary significantly among the species. The lowest values were found for Pododesmus macrochisma and the freshwater gastropod with about $0.6 \%$ and $0.7 \%$ water, respectively. Most of the molluscs contain about $1 \%$ or slightly more water in their shells. The freshwater clam from Lake Huron has up to $1.7 \%$ water and the red algae examined provides the maximum amount found with $2.2 \%$.

Results for Mytilus edulis and Pododesmus macrochisma require some clarification. Variable recoveries for these taxa call into question whether extractions are quantitative for 
TABLE 3. Results of thermal decrepitation of fluid inclusions in biogenic carbonates. $T$ ${ }^{\circ} \mathrm{C}$ represents the maximum temperature of decrepitation. Samples with asterisks were not treated with $\mathrm{H}_{2} \mathrm{O}_{2} . \delta^{18} \mathrm{O}$ and $\delta \mathrm{D}$ (SMOW) are given for trapped waters with their amounts. $\mathrm{Mole} \% \mathrm{CO}_{2}$ is the amount of $\mathrm{CO}_{2}$ extracted with $\mathrm{H}_{2} \mathrm{O}$ during the decrepitation procedure. The $\delta^{18} \mathrm{O}$ value of this $\mathrm{CO}_{2}$ is given relative to SMOW.

\begin{tabular}{|c|c|c|c|c|c|c|c|}
\hline Sample & $T^{9} \mathrm{C} *$ & $\%$ water & $\% \mathrm{mols}_{\mathrm{SO}}$ & $8 D$ & $\begin{array}{r}\delta^{18} \mathrm{O} \\
\left(\mathrm{H}_{2} \mathrm{O}\right)\end{array}$ & $\begin{array}{r}8^{18} \mathrm{O} \\
\left(\mathrm{CO}_{2}\right)\end{array}$ & $\begin{array}{r}8^{13} \mathrm{C} \\
\left(\mathrm{CO}_{2}\right)\end{array}$ \\
\hline Pododesmus macrochisma & 423 & 0.62 & 21.15 & -44.9 & 13.7 & n.d. & n.d. \\
\hline Pododesmus macrochisma & 405 & 0.71 & 19.19 & -48.0 & 10.2 & 37.3 & 0.15 \\
\hline Pododesmus macrochisma & 317 & 0.36 & 15.31 & -54.1 & 10.4 & 40.7 & -0.91 \\
\hline Anadara notabilis & 352 & 0.92 & 8.76 & -22.9 & 15.7 & 41.6 & 0.13 \\
\hline Anadara notabilis & 192 & 0.96 & 4.97 & -24.4 & 18.4 & 47.8 & 2.10 \\
\hline Anadara notabilis & 187 & 1.10 & 4.34 & -22.6 & 17.1 & 47.2 & 1.81 \\
\hline Anadara notabilis & 222 & 1.00 & 4.70 & -23.8 & 17.7 & 46.5 & 1.96 \\
\hline Anadara notabilis & 291 & 0.99 & 8.28 & -25.3 & 16.6 & 39.2 & 0.51 \\
\hline Anadara notabilis & 350 & 1.01 & 10.43 & -27.7 & 15.6 & 38.4 & 0.23 \\
\hline Anadara notabilis & 310 & 0.80 & 8.32 & -32.5 & 17.9 & 43.6 & 1.12 \\
\hline Anadara notabilis & 519 & 1.20 & 15.11 & n.d. & 16.4 & 33.4 & 0.51 \\
\hline Anadara notabilis ** & 298 & 0.97 & 5.05 & -32.4 & 19.1 & n.d. & n.d. \\
\hline Arca zebra & 287 & 1.00 & 8.94 & -21.7 & 9.4 & 46.9 & -2.08 \\
\hline Arca zebra & 215 & 1.00 & 7.49 & -31.0 & 9.3 & 46.1 & -1.14 \\
\hline Arca zebra & 256 & 0.92 & 10.24 & -28.9 & 9.5 & 43.4 & -1.30 \\
\hline Arca zebra & 354 & 1.16 & 13.76 & -28.7 & 9.3 & 35.9 & -0.30 \\
\hline Arca zebra ** & 397 & 1.00 & 9.18 & -32.9 & n.d. & 40.1 & 0.67 \\
\hline Arca zebra & 550 & 1.05 & 37.66 & n.d. & 10.4 & 33.3 & 0.85 \\
\hline Strombus gigas ** & 215 & 1.12 & 10.41 & -81.2 & 13.2 & 46.9 & -0.92 \\
\hline Strombus gigas & 221 & 1.14 & 13.39 & -75.5 & 13.4 & 44.1 & -0.60 \\
\hline Strombus gigas & 329 & 1.20 & 14.66 & -71.1 & 15.1 & 41.5 & -0.79 \\
\hline Strombus gigas & 440 & 1.25 & 16.36 & -73.4 & 15.6 & 38.9 & -1.79 \\
\hline Strombus gigas & 484 & 1.21 & 16.34 & n.d. & 16.0 & 38.7 & -1.00 \\
\hline Cittarium pica & 296 & 1.26 & 8.87 & -34.6 & 14.5 & 46.3 & 0.01 \\
\hline Cittarium pica & 262 & 1.23 & 11.18 & -25.7 & 12.9 & 46.2 & -1.49 \\
\hline Cittarium pica & 303 & 1.31 & 11.50 & -30.1 & 12.8 & 45.8 & -0.43 \\
\hline Merceneria merceneria & 308 & 1.45 & 10.19 & -44.3 & 8.1 & 39.1 & -0.58 \\
\hline Merceneria merceneria & 304 & 1.61 & 8.85 & -37.6 & 6.6 & 38.1 & -0.99 \\
\hline Merceneria merceneria & 315 & 1.69 & 8.25 & -36.1 & 6.6 & 38.0 & -0.97 \\
\hline Mytilus edulis & 359 & 2.24 & 8.41 & -26.0 & 10.9 & 45.3 & 2.07 \\
\hline Mytilus edulis & 356 & 1.21 & n.d. & -33.1 & n.d. & n.d. & n.d. \\
\hline Mytilus edulis & 253 & 0.74 & n.d. & -28.8 & 12.0 & n.d. & n.d. \\
\hline Freshwater clam & 292 & 1.76 & 8.54 & -61.9 & 6.1 & 44.6 & -6.41 \\
\hline Freshwater clam & 302 & 1.71 & 9.46 & -63.7 & 6.5 & n.d. & n.d. \\
\hline Freshwater gastropod & 301 & 0.70 & 8.90 & -81.1 & 9.8 & 38.7 & -2.45 \\
\hline Freshwater gastropod & 265 & 0.72 & 8.31 & -77.0 & 9.4 & 39.4 & -3.15 \\
\hline Freshwater gastropod & 300 & 0.71 & 12.50 & -75.7 & 11.4 & 38.1 & -2.17 \\
\hline Coral & 290 & 0.94 & 10.89 & -13.2 & 16.2 & 41.9 & -1.50 \\
\hline Coral & 294 & 1.06 & 7.73 & -18.4 & 17.2 & 42.6 & -1.30 \\
\hline Red algae & 290 & 2.33 & 19.32 & 35.6 & 12.2 & 41.7 & 5.14 \\
\hline Red algae & 254 & 2.21 & 18.23 & 21.3 & 11.8 & 43.2 & 7.28 \\
\hline
\end{tabular}

* maximum temperature of decrepitation

** sample not treated with $\mathrm{H}_{2} \mathrm{O}_{2}$

$\delta^{18} \mathrm{O}$ values of $\mathrm{H}_{2} \mathrm{O}$ and $\mathrm{CO}_{2}$ are relative to $\mathrm{SMOW}$

$\delta^{13} \mathrm{C}$ values of $\mathrm{CO}_{2}$ are relative to $\mathrm{PDB}$

n.d. : no determined

this kind of shell. Using TEM, TowE and THOMPSON (1972) found that the nacreous aragonite layers contain many more inclusions than the prismatic calcite layers of the Mytilus shell. It is possible that aliquots of shells used during the experiments came from different layers of the Mytilus shell. The other unusual result is the third extraction made of inclusions in Pododesmus macrochisma. Only $0.4 \%$ water was obtained as opposed to the $0.6-0.7 \%$ obtained from the previous two extractions (Table 3 ). This shell is the only one made of calcite and this particular extraction was inadvertently done at $317^{\circ} \mathrm{C}$ rather than the $400^{\circ} \mathrm{C}$ used for the other extractions. Calcite probably requires a higher temperature than aragonite to insure quantitative liberation of its inclusion fluids. The water obtained from the third extraction had an unusually low $\delta \mathrm{D}$ value, which more than likely signals an isotopic fractionation associated with incomplete extraction of water from the shell.

\section{Hydrogen and oxygen isotope compositions}

The $\delta^{18} \mathrm{O}$ and $\delta \mathrm{D}$ values of water trapped in the shells of eleven species are reported in the histograms of Fig. 2 . The $\delta^{18} \mathrm{O}$ values are all positive relative to SMOW and define a large field ranging from +6 to $+18 \%$. Average amounts of water are also reported for each species and do not correlate with $\delta{ }^{18} \mathrm{O}$ values of the trapped water. The measured $\delta \mathrm{D}$ values are all negative except for the red algae (discussed below) and range widely from -81 to $-13 \%$. In spite of the large range, and in contrast to the variable $\delta^{18} \mathrm{O}$ values, most of the $\delta \mathrm{D}$ values are around $-30 \%$. On a plot of $\delta \mathrm{D}$ vs. $\delta^{18} \mathrm{O}$, the data for each species define a distinct field (Fig. 3). Sometimes data within a given field scatter a few per mil in $\delta{ }^{18} \mathrm{O}$ and up to $10 \%$ in $\delta \mathrm{D}$ for different aliquots taken from the same animal (e.g., Anadara notabilis and Strombus gigas). The distribution of $\delta^{18} \mathrm{O}$ and $\delta \mathrm{D}$ values of trapped waters 

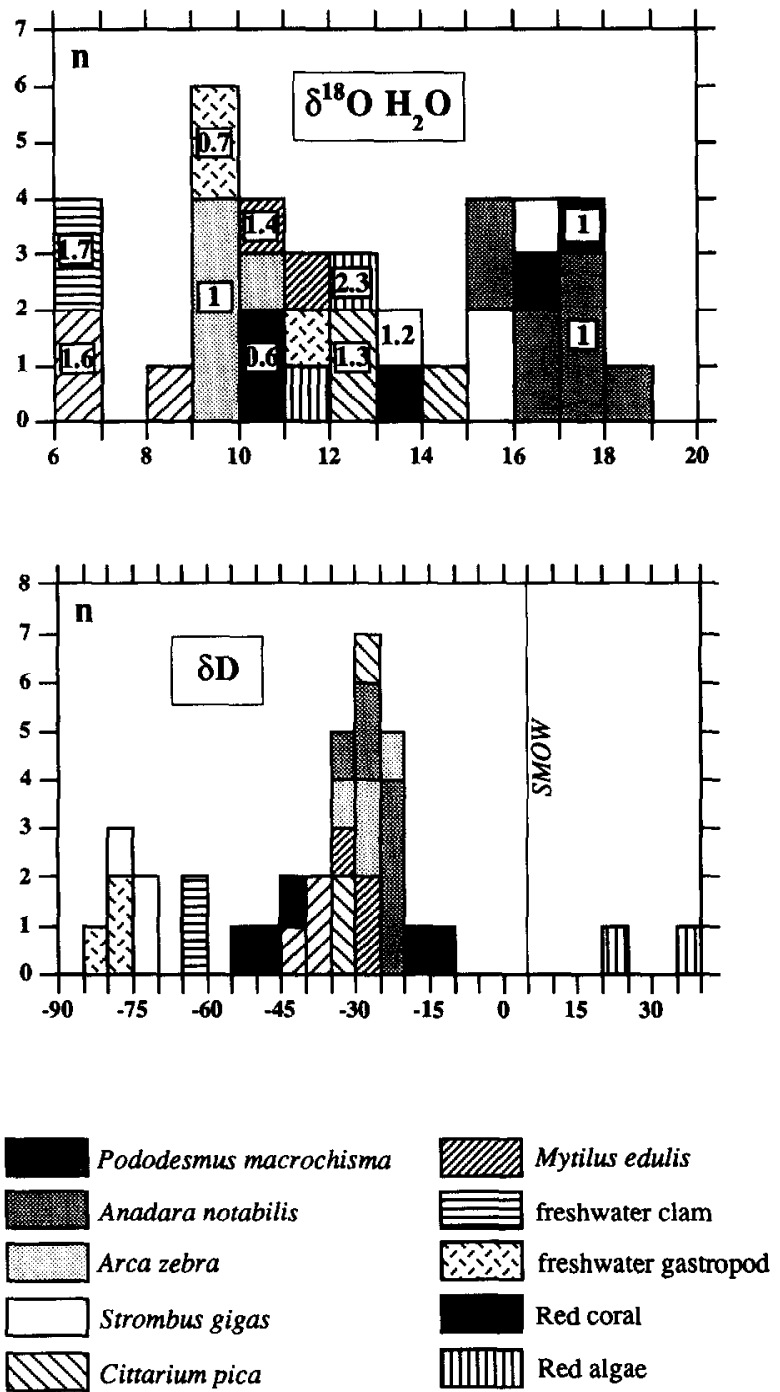

D7 Merceneria merceneria

FIG. 2. Frequency histograms of $\delta \mathrm{D}$ and $\delta^{18} \mathrm{O}$ values of water inclusions in biogenic carbonates with average amounts of water in weight $\%$ for each taxon. Note: only the data for samples treated with $\mathrm{H}_{2} \mathrm{O}_{2}$ are reported.

with respect to the sampling location of the shells is shown in Fig. 4. While no general rule is apparent, higher $\delta^{18} \mathrm{O}$ values for inclusion waters tend to occur in shells of organisms living in tropical areas like the Florida Keys or St. Maarten, whereas lower values tend to occur in organisms living in cold or freshwaters.

\section{$\mathrm{CO}_{2}$ Released During Thermal Decrepitation}

Small amounts of $\mathrm{CO}_{2}$ are also liberated with $\mathrm{H}_{2} \mathrm{O}$ during the thermal decrepitation of fluid inclusions. The amounts of $\mathrm{CO}_{2}$ liberated are generally small ( 5 to 15 mole\%) compared to the amounts of $\mathrm{H}_{2} \mathrm{O}$ ( Table 3). The amount of $\mathrm{CO}_{2}$ liberated, however, becomes important (up to $38 \mathrm{~mol} \%$ ) when the temperature of decrepitation exceeds $500^{\circ} \mathrm{C}$ because extensive decarbonation of the shells occurs at about this tem- perature. As a general rule, the amount of $\mathrm{CO}_{2}$ is well correlated with the peak temperature of decrepitation, this temperature being maintained for about two-thirds of the duration of the experiment. On the other hand, the $\delta^{18} \mathrm{O}$ value of this $\mathrm{CO}_{2}$ is inversely correlated with the same peak temperature. The correlation $(r=0.94)$ between temperature of decrepitation (over the range $170-580^{\circ} \mathrm{C}$ ) and $\delta^{18} \mathrm{O}$ value of $\mathrm{CO}_{2}$ extracted from Anadara notabilis is shown in Fig. 5. Note that at low temperatures where the amount of $\mathrm{CO}_{2}$ is very low (down to $3 \mu \mathrm{mol}$ ), the $\delta^{18} \mathrm{O}$ values are very high (up to $50 \%$ ), whereas at high temperatures the $\delta^{18} \mathrm{O}$ values tend to be close to the $\delta^{18} \mathrm{O}$ value of the shell as expected (Fig. 5).

In contrast to the regular variation of $\delta^{18} \mathrm{O}$ values with peak temperature of decrepitation, the $\delta^{13} \mathrm{C}$ values of the released $\mathrm{CO}_{2}$ vary in patterns that appear to be different from species to species (Fig. 6). In the case of Anadara notabilis, positive $\delta^{13} \mathrm{C}$ values characterize $\mathrm{CO}_{2}$ released at low temperatures, but they decrease toward $0 \%$ around $350^{\circ} \mathrm{C}$ and rise again at high temperatures to reach the $\delta^{13} \mathrm{C}$ value of the shell itself. $\delta^{13} \mathrm{C}$ values of $\mathrm{CO}_{2}$ produced by Arca zebra are negative at low temperatures, down to $-2 \%$, and increase with temperature to reach a value of $1 \%$, a value close to that of the host shell. Strombus gigas provides yet another pattern with $\delta^{13} \mathrm{C}$ values that remain negative without defining a trend with increasing temperature.

\section{EVALUATION OF ANALYTICAL DATA}

The positive $\delta^{18} \mathrm{O}$ values and the highly negative $\delta \mathrm{D}$ values of the inclusion waters are clear indications that these waters are not in equilibrium with either the host carbonate or the environmental water. Constancy in the amounts of water extracted for the same species, and the relative uniformity of $\delta \mathrm{D}$ values argue against any major analytical errors. While carbonates present unique problems, the techniques we are employing in this work are similar to established techniques

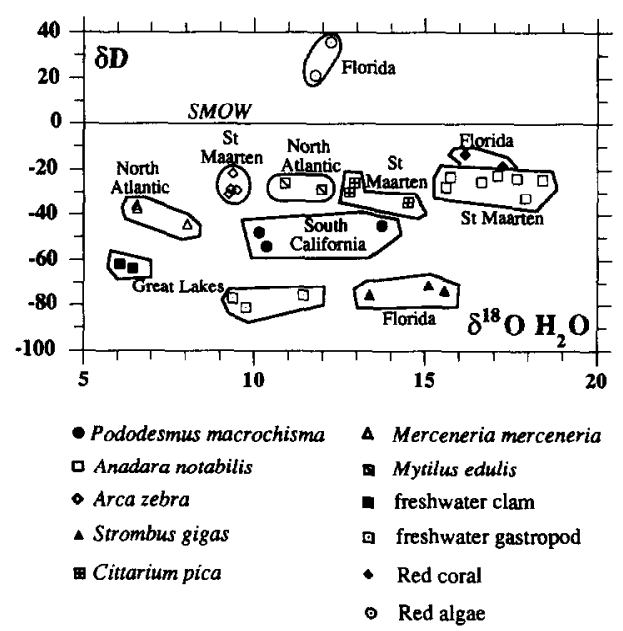

FIG. 3. Variations of $\delta^{18} \mathrm{O}$ and $\delta \mathrm{D}$ values of water inclusions in biogenic carbonates from North America and Carribean Islands. Analysis in the fields North Atlantic correspond to different animals, others correspond to different aliquots from the same animal. Note: only the data for samples treated with $\mathrm{H}_{2} \mathrm{O}_{2}$ are reported. 


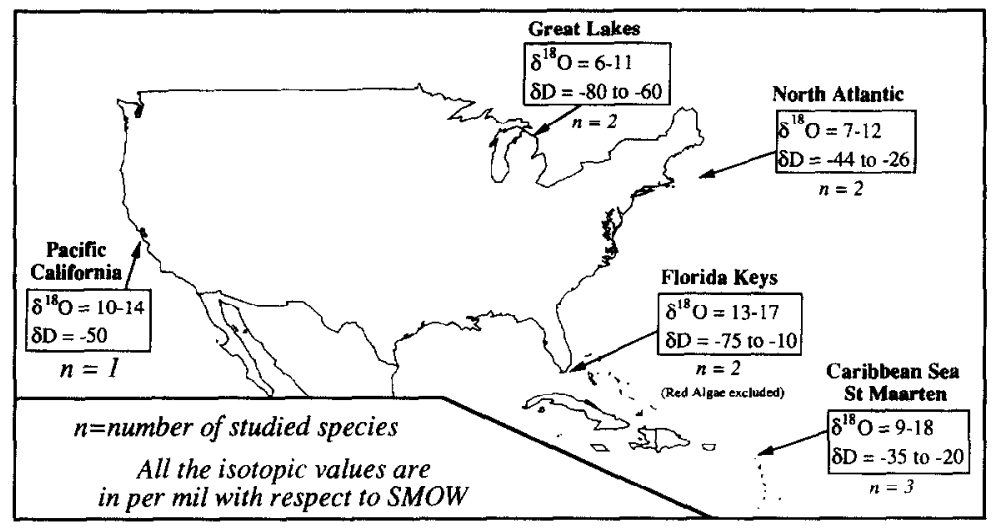

FIG. 4. Spatial distribution of $\delta \mathrm{D}$ and $\delta^{18} \mathrm{O}$ values of water inclusions in marine and freshwater biogenic carbonates. Ranges of values obtained by different experiments are given for each area. All the isotopic values are presented in per mil relative to SMOW. Note: only the data for samples treated with $\mathrm{H}_{2} \mathrm{O}_{2}$ are reported.

used by us and others to make quantitative extractions of inclusion fluids from several other minerals (quartz, halite, fluorite, copper, etc.). Also, the observed scatter in the present data is not systematic. For example, there is effectively no scatter in the analyses of water from Arca zebra (Table 3; Fig. 3).

There is some scatter in the oxygen isotope compositions of waters extracted from different aliquots of the same specimen or from different specimens of the same species. In addition, the hydrogen isotope compositions are quite different from those of the environmental waters. Are these measured isotopic compositions and variations real and natural or are they merely reflections of experimental artifacts? To resolve this question, possible sources of contamination and isotopic fractionation in our analytical procedures were tested and evaluated.

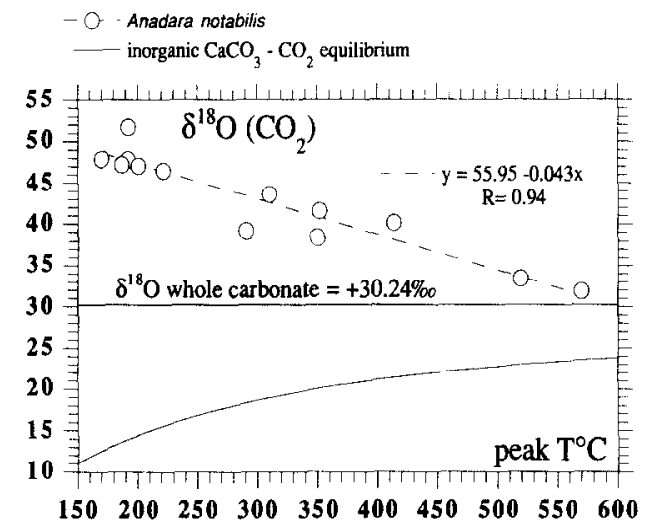

FIG. $5 . \delta^{18} \mathrm{O}$ values of $\mathrm{CO}_{2}$ released from Anadara notabilis during thermal decrepitation experiments as a function of the peak temperature. The curved line represents calculated values for $\mathrm{CO}_{2}$ in equilibrium with inorganic $\mathrm{CaCO}_{3}$ (BOTTINGA, 1968). The dashed line is a regression line interpreted as a mixing line between decarbonation $\mathrm{CO}_{2}$ and a ${ }^{18} \mathrm{O}$-rich $\mathrm{CO}_{2}$ component. The $\delta^{18} \mathrm{O}$ value of 30.24 for Anadara notabilis is relative to SMOW and was calculated using data from Table 2. Note: more oxygen isotopic analysis of $\mathrm{CO}_{2}$ are presented in this figure than in the Table 3 because neither $\delta^{18} \mathrm{O}$ values nor amounts of water were measured during these experiments. See text for interpretation of the different curves.

\section{Exchange Between Inclusion Water and Host}

A possible source of scatter in the data is oxygen isotope exchange between water and carbonate during thermal decrepitation. That is, we must consider whether the uniformly positive $\delta^{18} \mathrm{O}$ values of the waters could result from partial exchange with the host carbonate during the thermal decrepitation processes whose duration is typically less than 20 min. In fact, the bulk of the water is released and trapped in less than a minute or two, but heating and trapping are allowed to proceed for a much longer time to assure complete removal and transfer of any water that might be adsorbed on the fresh surfaces of the decrepitated carbonate. On the basis of cxperiments by O'NEIL et al. (1969), no significant oxygen isotope exchange between carbonates and water is anticipated at these temperatures in such short periods of time. Nonetheless, to test this possibility further, two plots were made. Figure 7 is a plot of $\delta^{18} \mathrm{O}$ (PDB) of the carbonate hosts against the $\delta^{18} \mathrm{O}$ (SMOW) of their trapped waters. The diagram shows clearly that the oxygen isotope composition of the host has

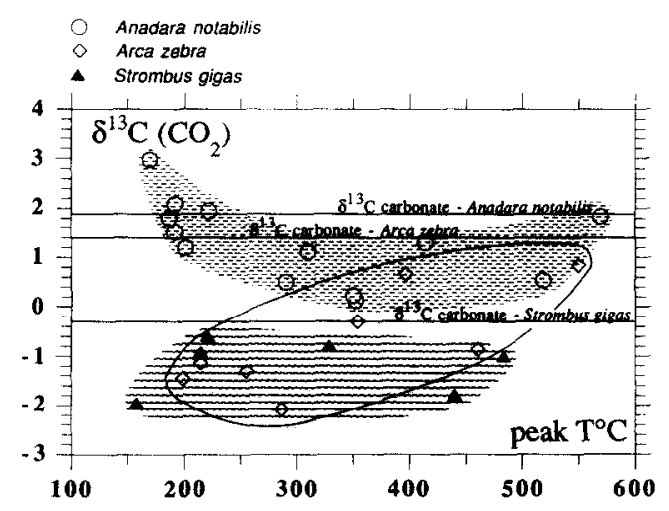

FIG. $6 . \delta^{13} \mathrm{C}$ values of $\mathrm{CO}_{2}$ released from Anadara notabilis during thermal decrepitation experiments as a function of the peak temperature. Fields were added to facilitate the distinction between isotopic compositions for the three species studied. Note: more carbon isotopic analysis of $\mathrm{CO}_{2}$ are presented in this figure than in Table 3 because neither $\delta^{18} \mathrm{O}$ values nor amounts of water were measured during these experiments. 


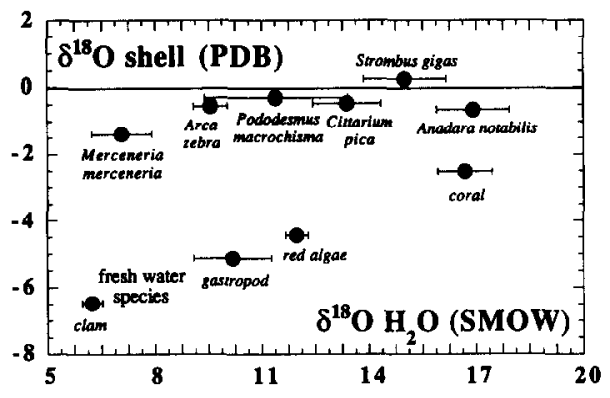

FIG. 7. $\delta^{18} \mathrm{O}$ values of whole shells (PDB) versus $\delta^{18} \mathrm{O}$ values of water inclusions (SMOW).

no control on the oxygen isotope composition of the inclusion waters. In Fig. 8, the $\delta^{18} \mathrm{O}$ and $\delta \mathrm{D}$ values are plotted against the peak temperature of decrepitation recorded during each experiment (Table 3 ). There is no correlation between the $\delta^{18} \mathrm{O}$ values of trapped water and the peak temperature regardless of whether we consider the data as a whole or each species individually. It is concluded that any isotopic exchange between carbonate and trapped fluids during decrepitation is negligible.

\section{Release of $\mathrm{CO}_{2}$}

The amount of $\mathrm{CO}_{2}$ released during decrepitation at low temperatures is very small, generally less than $15 \mu \mathrm{mol}$. Unlike the solid carbonate, this $\mathrm{CO}_{2}$ is likely to exchange oxygen isotopes with the trapped water and, in fact, the $\delta^{18} \mathrm{O}$ values of the $\mathrm{CO}_{2}$ (Table 3 ) correlate very well with the peak temperature of decrepitation (Fig. 5). As was shown in Fig. 8, there is no detectable correlation between the $\delta^{18} \mathrm{O}$ of $\mathrm{H}_{2} \mathrm{O}$ and the temperature (except maybe a small effect for Strombus gigas) so the presence of small amounts of $\mathrm{CO}_{2}$ do not affect the isotopic compositions of waters. The explanation is simply a matter of mass balance considerations and starting isotopic compositions. At low decrepitation temperatures $\left(200^{\circ} \mathrm{C}\right)$, the amounts of $\mathrm{CO}_{2}$ released are very small $(\approx 5$ $\mu \mathrm{mol})$ compared to the amounts of water (100-150 $\mu \mathrm{mol})$, and the $\delta^{18} \mathrm{O}$ values of $\mathrm{CO}_{2}$ already present as $\mathrm{CO}_{2}$ in the shell should have been in isotopic equilibrium with the inclusion water at ambient temperatures. Indeed, $\delta^{18} \mathrm{O}$ values of $\mathrm{CO}_{2}$ are very high, up to $50 \%$, as expected from equilibrium fractionations between $\mathrm{CO}_{2}$ and $\mathrm{H}_{2} \mathrm{O}$ at ambient temperatures (O'NEIL and ADAMI, 1969). In fact, these high $\delta^{18} \mathrm{O}$ values of trapped $\mathrm{CO}_{2}$ were the first indications we had that the inclusion waters were so heavy. The straight line relation of Fig. 5 can be interpreted as a mixing line between two $\mathrm{CO}_{2}$ endmembers: one with high $\delta^{18} \mathrm{O}$ values and corresponding to indigenous $\mathrm{CO}_{2}$ in the shell material and the other that results from progressive decarbonation of $\mathrm{CaCO}_{3}$ with increasing temperature. For comparison, $\delta^{18} \mathrm{O}$ values of $\mathrm{CO}_{2}$ in equilibrium with inorganic $\mathrm{CaCO}_{3}$ at various temperatures are represented by the curved line in Fig. 5 .

In the three cases examined, the distribution of $\delta^{13} \mathrm{C}$ values of $\mathrm{CO}_{2}$ as a function of temperature of release $\left(150-550^{\circ} \mathrm{C}\right)$ appears to be species-dependent (Fig. 6) with the $\delta^{13} \mathrm{C}$ values generally lower than those of the host shells by up to $2 \%$. At high temperatures, the $\delta^{13} \mathrm{C}$ values of $\mathrm{CO}_{2}$ tend to be close to those of the carbonate and thus retain the isotopic characteristics of the species and the living environment even after treatment with $\mathrm{H}_{2} \mathrm{O}_{2}$.

\section{Bound Water}

GAFFEY (1988) discussed the existence of bound water in biogenic carbonates. We must consider if this bound water (when it is present) can contribute significantly to the total amount of water extracted and modify the original oxygen isotope composition of free water. Bound water should have a lower ${ }^{18} \mathrm{O} /{ }^{16} \mathrm{O}$ ratio than carbonate oxygen by analogy with the oxygen isotope properties of $\mathrm{OH}$ groups in hydrous minerals and waters of crystallization (e.g., O'NEIL, 1986). In addition, bound water should be released at temperatures considerably higher than the release temperatures of free water. GAFFEY (1988) observed that only free water is present in coelenterata (coral) skeletons. While water extracted from coral has some of the highest $\delta^{18} \mathrm{O}$ values measured in this study $(16-17 \%$ ), in keeping with the absence of isotopically light bound water, a more sensible explanation for the relative ${ }^{18} \mathrm{O}$ enrichment will be provided below. Any contribution of bound water in our experiments must be negligible because (1) bound water exists in only minor amounts when present, and (2) there is no significant correlation between peak decrepitation temperature and either amounts of water or $\delta^{18} \mathrm{O}$ values.

\section{Consequences of the $\mathrm{H}_{2} \mathrm{O}_{2}$ Treatment}

Fractions to a few percent of organic matter is commonly integrated within the shell of biogenic carbonates (WoLF et al., 1967; YOUNG, 1971; GREEN et al., 1980). Samples were
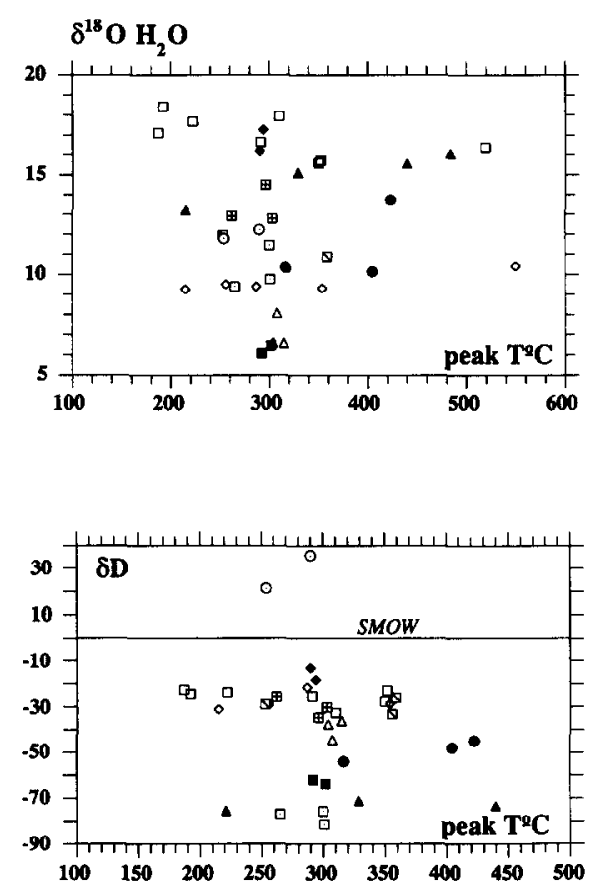

FIG. 8. $\delta^{18} \mathrm{O}$ and $\delta \mathrm{D}$ values of water inclusions versus peak temperature of decrepitation. Same legend as in Fig. 4. Note: only the data for samples treated with $\mathrm{H}_{2} \mathrm{O}_{2}$ are reported. 
treated with $\mathrm{H}_{2} \mathrm{O}_{2}$ to prevent contribution of water released by organic matter (or any exchange reactions with such material) during thermal degradation. Failure to detect organic carbon by coulometry in the sample after $\mathrm{H}_{2} \mathrm{O}_{2}$ treatment confirms that this treatment is very effective in removing organic matter from the shells.

The possible contribution of water coming from organic matter or possible perturbations of the isotopic composition of fluid inclusions during treatment with $\mathrm{H}_{2} \mathrm{O}_{2}$ were tested using three different species. The stable isotope ratios of trapped waters and the organic C contents of Anadara notabilis, Arca zebra, and Strombus gigas were measured before and after $\mathrm{H}_{2} \mathrm{O}_{2}$ treatment. The data are presented in Table 4 .

Within the limits of experimental error, the amount of extractable water does not change after treatment (Table 3). The $\delta \mathrm{D}$ values before treatment are slightly lower by about $6 \%$ suggesting that a small amount of organic-derived water may contaminate the trapped water. $\mathrm{CHAREF}$ and SHEPPARD (1984) suggested that organic water in nature could have $\delta \mathrm{D}$ values as low as $-250 \%$. The deduced small amount of contaminating organic water is also in agreement with the low contents of organic carbon analyzed in these shells.

The two $\delta^{18} \mathrm{O}$ values determined for untreated Anadara notabilis and Arca zebra are relatively close to the range found during experiments done on treated samples. The highest $\delta^{18} \mathrm{O}$ value of $19.1 \%$ is close to the value of $18.4 \%$ measured on another part of the shell treated with $\mathrm{H}_{2} \mathrm{O}_{2}$. It is not possible to detect important modifications of the $\delta^{18} \mathrm{O}$ values of the fluids as a result of $\mathrm{H}_{2} \mathrm{O}_{2}$ treatment, and the low amplitude deviations of $\delta \mathrm{D}$ suggest that the contribution of organicderived waters is weak or absent. This conclusion is in agreement with that of HUDSON (1967) who considers that $\mathrm{H}_{2} \mathrm{O}$ formed by oxidation of organic matter is not a major contributor to the total water content of shell material and could exert only a second-order effect at most. The use of $\mathrm{H}_{2} \mathrm{O}_{2}$ does not affect the stable isotope compositions of fluid inclusions and effectively eliminates any contribution of extraneous waters that could become significant for samples that are rich in organic matter.

\section{ORIGIN OF TRAPPED WATER IN BIOGENIC CARBONATES}

From the arguments presented above, the decrepitated waters are unaltered samples of water trapped in the carbonate presumably at the time of shell formation. The measured $\delta{ }^{18} \mathrm{O}$ and $\delta \mathrm{D}$ values are thus a clear indication that such water does not represent remnants of environmental waters. More likely these fluids are trapped body fluids whose isotopic composition is controlled by biological factors.

In molluscs, shell aragonite or calcite is deposited from the solution termed the extrapallial fluid, which is secreted by the epithelium of the outer mantle (DEWAELE, 1930). The function of the extrapallial fluid is to derive the necessary mineralizing elements from the blood of the organism which, in turn, acquires them from the environmental water. This complex process is effective in partitioning trace elements (SPEER, 1990). In fact, the only fluid thought to be in internal contact with the shell during its formation is the extrapallial fluid whose composition is known to be controlled by metabolic processes.

LUZ and KOLODNY (1985) have shown that the body fluids of mammals and other vertebrates have $\delta^{18} \mathrm{O}$ values that are several per mil higher than those of local drinking water, the presumed major source of oxygen used by the organisms. The cause of ${ }^{18} \mathrm{O}$-enrichment is incorporation of atmospheric $\mathrm{O}_{2}$ and oxygen of organic food components which interact with body water via their metabolic products $\mathrm{H}_{2} \mathrm{O}$ and $\mathrm{CO}_{2}$.

In the case of the molluscs, the main species studied here (nine species out of eleven), shell formation depends on energy made available by the metabolism of the mantle. Metabolism is the aggregate of all chemical reactions that occur in living tissue and the respiratory rate is a fairly good indicator of its magnitude (HAMMEN, 1980). Food is used as a source of energy, and through respiration it is ultimately broken down by oxidation processes into carbon dioxide and water. RAKESTRAW et al. ( 1951 ) and KROOPNICK and CRAIG (1976) demonstrated that the ${ }^{18} \mathrm{O} /{ }^{16} \mathrm{O}$ ratio of dissolved oxygen in the oceans is higher than that of atmospheric oxygen due to preferential consumption of ${ }^{16} \mathrm{O}$ by bacteria in ocean waters. Because atmospheric oxygen has a high $\delta^{18} \mathrm{O}$ value of 23\% (KROOPNICK and CRAIG, 1972), it is not surprising that body fluids are relatively ${ }^{18} \mathrm{O}$ rich but never exceed the values of atmospheric oxygen. Metabolic rates of animals and coupled amounts of absorbed food can be estimated from the rate of oxygen consumption. But the rate of oxygen consumption depends on intrinsic parameters like body size, activity, endogeneous rhythms, growth, and reproduction (HUGHES, 1986). For example, smaller individuals respire faster than larger ones. Extrinsic determinants of this parameter are temperature, partial pressure of oxygen, salinity, respiration in air or water, and food supply.

TABLE 4. $\delta \mathrm{D}$ and $\delta^{18} \mathrm{O}$ (in \%o vs SMOW) values of trapped waters are given for three species treated with $\mathrm{H}_{2} \mathrm{O}_{2}$ and untreated. Amounts of organic $\mathrm{C}$ are given for Arca zebra and Strombus gigas before the $\mathrm{H}_{2} \mathrm{O}_{2}$ treatment. Analysis of organic $\mathrm{C}$ was made coulometrically.

\begin{tabular}{|c|c|c|c|c|c|}
\hline Genus & $\begin{array}{c}\text { untreated } \\
\delta D(\% 0 S M O W)\end{array}$ & $\begin{array}{c}\mathrm{H}_{2} \mathrm{O}_{2} \text { treated } \\
\delta \mathrm{D}(\% a \mathrm{SMOW}) \\
\text { average valuc }\end{array}$ & $\begin{array}{c}\text { untreated } \\
\delta{ }^{18} \mathrm{O}(\% \text { aSMOW) }\end{array}$ & $\begin{array}{c}\mathrm{H}_{2} \mathrm{O}_{2} \text { treated } \\
\delta 18 \mathrm{O}(\% \circ \text { SMOW) } \\
\text { average value }\end{array}$ & $\%$ organic $\mathrm{C}$ \\
\hline Anadara notabilis & -32 & $-26 \pm 3$ & 19.1 & $16.9 \pm 1.0$ & n. d. \\
\hline Arca zebra & -33 & $-27 \pm 4$ & n.d. & $9.6 \pm 0.5$ & 0.9 \\
\hline Strombus gigas & -81 & $-73 \pm 2$ & 13.2 & $15.0 \pm 1.2$ & 0.15 \\
\hline
\end{tabular}


The positive and varying $\delta^{18} \mathrm{O}$ values recorded by the trapped waters in the shells can be explained by a combination of multiple factors that integrate the isotopic composition of environmental water and the metabolic rate of each species, itself a function of living temperature, food supply, body size, etc. In agreement with this interpretation, corals live in tropical waters, have high metabolic rates, and the inclusion waters in their shells have high $\delta^{18} \mathrm{O}$ values. The lowest $\delta^{18} \mathrm{O}$ values measured for trapped waters in shells are for organisms living in isotopically light and cold waters.

The absence of a correlation between the $\delta^{18} \mathrm{O}$ values of carbonate hosts and their trapped waters accentuates those cases where fluids trapped in the shell structure have high $\delta^{18} \mathrm{O}$ values and the carbonate shells themselves have $\delta^{18} \mathrm{O}$ values that correspond to isotopic equilibrium with the environmental water, as shown by the data for Anadara notabilis, Strombus gigas, or Cittarium pica. These observations could mean that, in most cases, metabolic $\mathrm{H}_{2} \mathrm{O}$ does not exchange oxygen isotopes with the $\mathrm{HCO}_{3}^{-}$ion that is taken directly from ambient water and incorporated into the shell as $\mathrm{CO}_{3}^{2-}$ ions via enzymatic activity (WILBUR and SALEUDDIN, 1983). Complicating the issue is the fact that $\mathrm{H}_{2} \mathrm{O}$ fluxes between the organism and seawater are probably much higher than the metabolic fluxes (MCCONNAUGHEY, 1989b) that might be responsible for producing relatively ${ }^{18} \mathrm{O}$-rich internal water. In fact, passive water diffusion across membranes should be about a million times faster than the generation of ${ }^{18} \mathrm{O}$-rich water from respiration.

The release of $\mathrm{CO}_{2}$ at the lowest temperatures of decrepitation may provide an important clue to unravelling the isotopic systematics of shells and the nature of their inclusion fluids. Several points are pertinent to understanding this and related observations: (1) The trapped $\mathrm{CO}_{2}$ is in near isotopic equilibrium with the inclusion waters and thus, must be present in intimate contact with the inclusion water in the shell; (2) inclusion $\mathrm{CO}_{2}$ and $\mathrm{H}_{2} \mathrm{O}$ have incorporated ${ }^{18} \mathrm{O}$-rich respiratory oxygen, but $\mathrm{CaCO}_{3}$ has not; (3) because removing organic matter does not release the high- ${ }^{18} \mathrm{O}$ fluids, it would appear that they are trapped as true fluid inclusions in the $\mathrm{CaCO}_{3}$ and not in interstices of the organic matrix; (4) carbonic anhydrase, an enzyme used by shell-bearing organisms, should promote rapid oxygen isotope exchange between water and dissolved $\mathrm{C}-\mathrm{O}$ species; and (5) $\mathrm{CO}_{2}$ is not a dominant species at a pH near 8 , implying that the trapped $\mathrm{CO}_{2}-\mathrm{H}_{2} \mathrm{O}$ mixtures have not been in contact with seawater.

Accounting for the above phenomena must involve complicated kinetic and equilibrium processes and bear on the timing of shell deposition relative to the timing of metabolic reactions. It would appear that the organisms deposit their shells from $\mathrm{HCO}_{3}^{-}$in the pallial fluid that is in isotopic equilibrium with the environmental water. Respircd $\mathrm{CO}_{2}$ and $\mathrm{H}_{2} \mathrm{O}$ must then be trapped at varying fast rates within the $\mathrm{CaCO}_{3}$ before having the opportunity to exchange with the pallial fluid. Such a proposal is at some variance with conventional views of shell deposition and will require future experiments to resolve the conflicts.

The $\delta \mathrm{D}$ values of the trapped waters are consistently lower than those of ambient waters, except for red algae. For marine species, typical $\delta \mathrm{D}$ values for the trapped waters are in the range -35 to $-20 \%$, contrasting strongly with $\delta \mathrm{D}$ values of less than $-60 \%$ for trapped waters in freshwater species (Fig. 2 ). The difference of 35 to $40 \%$ between the trapped waters is roughly equivalent to the difference in $\delta \mathrm{D}$ values between seawater $(0 \%)$ and Great lakes water $(-50$ to $-40 \%$ ).

EPSTEIN et al. (1976) demonstrated that hydrogen atoms bonded to oxygen in organic matter exchange readily with water even at low temperatures, whereas hydrogen bonded to carbon seems to be nonexchangeable. In molluscs, $\mathrm{H}_{2} \mathrm{O}$ is also thought to be associated with an organic matrix (GAFFEY, 1988; GAFFEY et al., 1991) and hydrogen isotope exchange could occur. In addition to our evidence that such water is normally not abundant, this process is unlikely because isotopic exchange with organic matter should cause an increase in $\delta \mathrm{D}$ of the fluid, a direction opposite to what is observed in our data, except for red algae. The low $\delta \mathrm{D}$ values of trapped waters in the carbonate shells could result from isotopic fractionations during the incorporation and metabolism of hydrogen from food. The large spread of $\delta \mathrm{D}$ values is in agreement with the data of SCHIEGL and VOGEL (1970) who analyzed marine plants and animals and observed $\delta \mathrm{D}$ values of lower than $-100 \%$ to about $-10 \%$. This large range of values was attributed to variations in the chemical composition of organic matter.

Figure 3 shows the variations in $\delta^{18} \mathrm{O}$ and $\delta \mathrm{D}$ values of waters extracted from different aliquots of the same sample. During crushing of the biogenic carbonates, grains from different parts of the shells were mixed without considering their provenance from the different layers. Metabolic activity and isotopic compositions of respired fluids may be influenced by environmental factors, especially temperature which varies seasonally. It has been known for a long time that there are fine-scale variations in $\delta{ }^{18} \mathrm{O}$ within a single shell as a consequence of seasonal variations in temperature and isotopic compositions of the environmental fluids (EPSTEIN and LOWENSTAM, 1953).

Changes in the isotopic composition of environmental water with seasonal variations can also be responsible for the scatter observed in $\delta^{18} \mathrm{O}$ and $\delta \mathrm{D}$ values of fluids from the same animal. All the molluscs studied (Table 1) are intertidal organisms (except algae and corals), and they are probably subjected to greater environmental fluctuations than are experienced in any other habitat. Complementary data are required to test whether these isotopic variations are seasonally controlled or not. Analysis of fluids from separate layers of large molluscs will be performed in a later study.

\section{CONCLUSIONS}

The following arguments suggest that natural and original fractionation processes are mainly responsible for the $\delta^{18} \mathrm{O}$ $\delta \mathrm{D}$ variations recorded by waters trapped in skeletal carbonate:

$1)$ each species defines a distinct field in $\delta^{18} \mathrm{O}-\delta \mathrm{D}$ space suggesting that isotopic variations are dominantly speciescontrolled;

2) scatter in the data is not systematic;

3) there is no correlation between the $\delta^{18} \mathrm{O}$ values of $\mathrm{H}_{2} \mathrm{O}$ and host carbonate;

4) there is no correlation between the $\delta^{18} \mathrm{O}$ value of $\mathrm{H}_{2} \mathrm{O}$ 
and either temperature or amount of $\mathrm{CO}_{2}$ released (excluding $\mathrm{CO}_{2}$ from decarbonation at high temperatures); and

5) $\delta \mathrm{D}$ values of inclusion $\mathrm{H}_{2} \mathrm{O}$ are very different from of ambient waters.

While interpretations of these preliminary isotopic data must remain tentative, the trapped waters in biogenic carbonates unquestionably cannot represent ambient waters. Furthermore, the association of positive $\delta^{18} \mathrm{O}$ values with negative $\delta \mathrm{D}$ values (except for the red algae), the speciescontrolled distribution of $\delta^{18} \mathrm{O}-\delta \mathrm{D}$ values, and the secondorder effects on $\delta^{18} \mathrm{O}$ values induced by the isotopic composition and temperature of ambient waters all support the interpretation that these trapped waters are remnants of metabolic fluids. The trapped fluids are often dominated by ${ }^{18} \mathrm{O}-$ rich respired $\mathrm{H}_{2} \mathrm{O}$ and $\mathrm{CO}_{2}$ that did not undergo isotopic exchange with pallial water. This interpretation is well supported by physiological properties of marine invertebrates but at some variance with conventional mechanisms of shell building. The isotopic characterization of these trapped waters could provide information about the metabolic activity of well-preserved fossils. Moreover, the stable isotope characteristics of these trapped waters could also be used as a diagnostic test of the preservation state of fossil biogenic carbonates. Loss of water during diagenesis and replacement by meteoric waters should be easily detected.

The experiments performed during this study showed that all water is liberated by aragonite shells above $200^{\circ} \mathrm{C}$ in a vacuum. GAFFEY (1988) and GAFFEY et al. (1991) suggested that the water in aqueous fluid inclusions could be sufficient to serve as a medium for diagenetic reactions affecting either other carbonates or associated silicate rocks. Isotopically, the waters contained in biogenic carbonates define a huge field of values determined so far with only eleven species but coming from contrasting environments. The $\delta^{18} \mathrm{O}-\delta \mathrm{D}$ fields, however, are distinctly different from those of meteoric, magmatic, or marine waters. The role of these trapped waters should not be neglected in some restricted geological contexts where the burial of significant amounts of biogenic carbonates can liberate enough water to participate in or initiate diagenetic or metamorphic reactions. The isotopic compositions of these waters can be a sensitive tracer for this kind of fluid particularly when other types of fluids are not abundant.

Acknowledgments-The authors are grateful to L. M. Walter who provided the shell samples from the Florida Keys and thank also T. Vennemann, K. C. Lohmann, and J. Burdett for assistance in the laboratory and valuable discussions. The manuscript was improved by suggestions from T. McConnaughey, E. Grossman, and P. Swart. This research was supported in part by NSF grant EAR9005717 to JRO.

Editorial handling: Henry P. Schwarcz

\section{REFERENCES}

BOTTINGA Y. ( 1968 ) Calculation of fractionation factors for carbon and oxygen isotopic exchange in the system calcite-carbon dioxidewater. J. Phys. Chem. 72, 800-808.

CARPENTER S. J. (1991) Isotopic and minor element chemistry of devonian-carboniferous abiotic marine calcite. Ph.D. thesis, Univ. Michigan.

ChareF A. and Sheppard S. M. F. (1984) Carbon and Oxygen isotope analysis of calcite or dolomite associated with organic matter. Chem. Geol. (Iso. Geosci.) 2, 325-333.

Craig H. and Gordon L. I. ( 1965 ) Deuterium and oxygen-18 variations in the ocean and the marinc atmospherc. In Stable Isotopes in Oceanographic Studies and Paleotemperatures (ed. E. ToNGIORGI), pp. 1-22. Spoleto, Consiglio Nazionale delle Ricerche, Lab. Geol. Nucl.

DEWAELE A. (1930) Le sang d'Anodonta cygnea et la formation de la coquille. Mém. Acad. R. Belg. Cl. Sci. 10, $1-5$ t.

EPSTEIN S. and LOWENSTAM H. (1953) Temperature-shell-growth relations of recent and interglacial Pleistocene shoal-water biota from bermuda. $J$. Geol. 61, 424-437.

EPSTEIN S. and MAYEDA T. K. (1953) Variation of ${ }^{18} \mathrm{O}$ content of waters from natural sources. Geochim. Cosmochim. Acta 4, 213224.

Epstein S., Buchsbaum R., Lowenstam H. A., and Urey H. C. (1953) Revised carbonate-water isotopic temperature scale. Geol. Soc. Am. Bull. 64, 1315-1326.

EPSTEIN S., YAPP C. J., and HALL J. H. (1976) The determination of the $\mathrm{D} / \mathrm{H}$ ratio of non-exchangeable hydrogen in cellulose extracted from aquatic and land plants. Earth Planet. Sci. Lett. 30, 241-251.

EREZ J. (1978) Vital effect on stable-isotope composition seen in foraminifera and coral skeletons. Nature 273, 199-202.

GAFFEY S. J. ( 1988 ) Water in skeletal carbonates. J. Sediment Petrol. 58, 397-414.

GafFey S. J., Kolak J. J., and Bronnimann C. E. (1991) Effects of drying, heating, annealing, and roasting on carbonate skeletal material, with geochemical and diagenetic implications. Geochim. Cosmochim. Acta 55, 1627-1640.

GOREAU T. J. (1977) Coral skeletal chemistry: physiological and environmental regulation of stable isotopes and traces metals in Montastrea annularis. Proc. Roy. Soc. London Ser. B196, 291315.

GREeN J. W., LipPS J. H., and Showers W. J. (1980) Test ultrastructure of fusulinid Foraminifera. Nature 283, 853-855.

HaMmen C. S. (1980) Marine Invertebrates, Comparative Physiology. Univ. Press New England.

Hudson J. D. (1967) The elemental composition of the organic fraction, and the water content of some recent and fossil mollusc shells. Geochim. Cosmochim. Acta 31, 2361-2378.

HUGHES R. N. ( 1986) A Functional Biology of Marine Gastropods. Johns Hopkins Univ. Press.

Kishima N. and SAK AI H. (1980) Oxygen- 18 and deuterium determination on a single water sample of a few milligrams. Anal. Chem. 52, 356-358.

KROOPNICK P. and CRAIG H. (1972) Atmospheric oxygen: Isotopic composition and solubility fractionation. Science 175, 54-55.

KROOPNICK P. and CRAIG H. (1976) Oxygen isotope fractionation in dissolved oxygen in the deep sea. Earth Planet. Sci. Lett. 32, 375-388.

LUZ B. and KoLoDNY Y. (1985) Oxygen isotope variations in phosphate of biogenic apatites, II. Mammal teeth and bones. Earth Planet. Sci. Lett. 75, 29-36.

MCCONNAUGHEY T. (1989a) ${ }^{13} \mathrm{C}$ and ${ }^{18} \mathrm{O}$ isotopic disequilibrium in biological carbonates: I. Patterns. Geochim. Cosmochim. Acta 53, 151-162.

MCConnaughey T. ( $1989 \mathrm{~b}){ }^{13} \mathrm{C}$ and ${ }^{18} \mathrm{O}$ isotopic disequilibrium in biological carbonates: II. In vitro simulation of kinetic isotope effects. Geochim. Cosmochim. Acta 53, 163-171.

O'NEIL J. R. ( 1986) Theoretical and experimental aspects of isotopic fractionation. In Stable Isotopes in High Temperature Geological Processes (ed. J. W. Valley, et al.); Rev. Mineral. 16, 1-40.

O'NEIL J. R. and ADAMI L. H. (1969) The oxygen isotope partition function ratio of water and the structure of liquid water. J. Phys. Chem. 73, 1553-1558.

O'Neil J. R., Clayton R. N., and MAYeda T. K. (1969) Oxygen isotope fractionation in divalent metal carbonates. J. Chem. Phys. 51, 5547-5558. 
Rakestraw N. W., Rudd D. P., and Dole M. (1951) Isotopic composition of oxygen in air dissolved in Pacific Ocean water as a function of depth. J. Amer. Chem. Soc. 73, 2976.

SCHIEGL W. E. and VoGEL J. C. (1970) Deuterium content of organic matter. Earth Planet. Sci. Lett. 7, 307-313.

SPEER J. A. (1990) Crystal chemistry and phase relations of orthorhombic carbonates. In Carbonates: Mineralogy and chemistry (ed. R. J. REEDER); Rev. Mineral. 11, 145-190.

SWART P. K. (1983) Carbon and oxygen isotope fractionation in scleractinian corals: A review. Earth Sci. Rev. 19, 51-80.

Towe K. M. and THOMPSON G. R. (1972) The structure of some bivalve shell carbonates prepared by ion-beam thinning. Calc. Tissue Res. 10, 38-48.

WEBER J. N. and RAUP D. M. (1966) Fractionation of the stable isotopes of carbonate and oxygen in marine calcareous organismsthe Echinoidea. Part I. Variation of $\mathrm{C}^{13}$ and $\mathrm{O}^{18}$ content within individuals. Geochim. Cosmochim. Acta 30, 681-703.
Weber J. N. and WOODHEAD P. M. J. (1970) Carbon and oxygen isotope fractionation in the skeletal carbonate of reef-building corals. Chem. Geol. 6, 93-117.

Weil. S. M., Buddemejer R. W., SMith S. V., and KroOpNick P. M. (1981) The stable isotopic composition of coral skeletons: Control by environmental variables. Geochim. Cosmochim. Acto 45, 1147-1153.

WILBUR K. M. and SALEUdDIN A. S. M. (1983) Shell formation. In The molluscs (ed. A. S. M. SALEUdDIN and K. M. WILBUR), pp. 235-287. Acad. Press.

WOLF K. H., EASTON A. J., and WARNE S. (1967) Techniques of examining and analyzing carbonate skeletons, minerals, and rocks. In Carbonate rocks (ed. G. V. CHILINGAR et al.), pp. 253-341. Elsevier.

YouNG S. D. (1971) Organic material from scleractinian coral skeletons-I. Variation in composition between several species. Comp. Biochem. Physiol. 40B, 113-120. 